\title{
Ultrastructural Localization of Polygalacturonase in Ethylene-Stimulated Abscission of Tomato Pedicel Explants
}

\author{
Ming-Fang Qi, ${ }^{1,2}$ Tao Xu, ${ }^{1,2}$ Wei-Zhi Chen, ${ }^{1,2}$ and Tian-lai Li ${ }^{1,2}$ \\ ${ }^{1}$ Department of Horticulture, Key Laboratory of Protected Horticulture, Ministry of Education, No. 120 Donglin Road, \\ Shenyang City, Liaoning 110866, China \\ ${ }^{2}$ Shenyang Agricultural University, No. 120 Donglin Road, Shenyang City, Liaoning 110866, China
}

Correspondence should be addressed to Ming-Fang Qi; qimingfang@126.com

Received 12 December 2013; Accepted 19 February 2014; Published 24 March 2014

Academic Editors: E. Bloem and A. M. De Ron

Copyright (C) 2014 Ming-Fang Qi et al. This is an open access article distributed under the Creative Commons Attribution License, which permits unrestricted use, distribution, and reproduction in any medium, provided the original work is properly cited.

\begin{abstract}
Polygalacturonase (PG) is crucial in plant organ abscission process. This paper investigated the cellular and subcellular localization of PG in ethylene-stimulated abscission of tomato pedicel explants. Confocal laser scanning microscopy of abscission zone sections with the fluorescent probe Cy3 revealed that PG was initially accumulated in parenchyma cells in cortical and vascular tissues after $8 \mathrm{~h}$ of ethylene treatment and then extended throughout the abscission zone when the abscission zone separated at $24 \mathrm{~h}$ after ethylene treatment. At the subcellular level, transmission electron microscopy with immunogold staining showed that PG showed abundant accumulation in the cortical and vascular tissues at $8 \mathrm{~h}$ after ethylene treatment, and the distribution area extended to the central parenchyma cells at $16 \mathrm{~h}$ after ethylene treatment. In addition, PGs were observed in the distal and proximal parts of the tomato pedicel explants throughout the abscission process. The results provided a visualized distribution of PG in the pedicel abscission zone and proved that PG was closely related to abscission.
\end{abstract}

\section{Introduction}

Abscission is the process in which organs are separated from the parent plant; this process involves multiple changes in cell structure, metabolism, and gene expression [1]. Abscission usually occurs in the abscission zone of plants. The abscission zone contains small, square-shaped cells with a dense cytoplasm $[2,3]$. Abscission has three classes, namely, normal abscission (such as abscission of ripened fruit and seed), metabolic abscission due to the completion of reproductive and vegetative growth (such as premature shedding of fruit and unpollinated flowers), and abscission due to environmental stresses (such as heat, cold, and light). The development and mechanisms of plant hormones, such as the interplay of ethylene and auxin, are well documented. However, detailed mechanisms on the regulation and control of these processes remain unknown.

Abscission signals, including environmental and developmental cues, can be sensed by the cells in the abscission zone. These signals initiate abscission. Plant hormones, especially ethylene and auxin, have important functions in abscission. Several studies have modeled the regulation of ethylene and auxin $[1,2,4,5]$. Ethylene accelerates abscission, whereas auxin restricts the process.

Studies have proven that cell wall hydrolases, such as $\beta$ 1,4-glucanase, polygalacturonase (PG), and chitinase, have important functions after the initiation of abscission $[3,6-$ 8]. Particularly, PGs are essential for the degradation of pectin, a crucial component of the adhesive material between cells. Gene expression profiling studies have shown that increased PG expression in abscission is closely related to flower abscission [7-11]. However, the location of PG protein in the abscission zone remains unclear. A recent study in tomato has suggested that enzyme expression and synthesis within abscission zone cells are asymmetric with regard to the proximal-distal axis [12]. Tomato flower pedicel is an ideal material to study abscission because of its prominent abscission zone. The current study aims to locate PGs in the tomato abscission zone during ethylene-induced abscission using immunogold staining. 


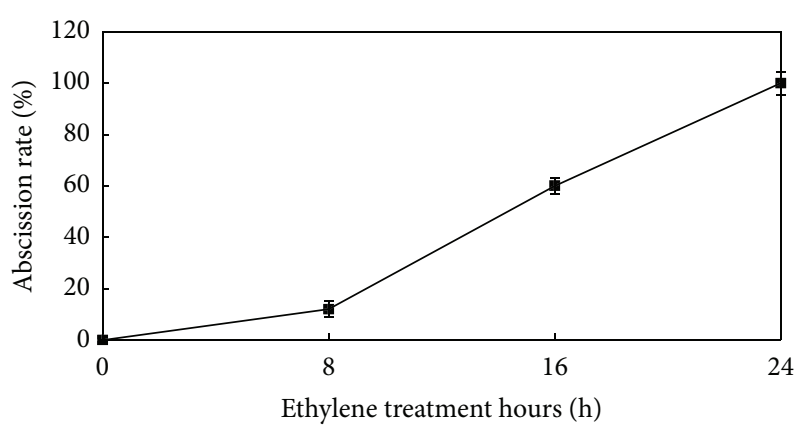

FIGURE 1: Effect of ethylene on abscission rate of tomato pedicel explants. Vertical bars indicate \pm S.E. $(n=3)$.

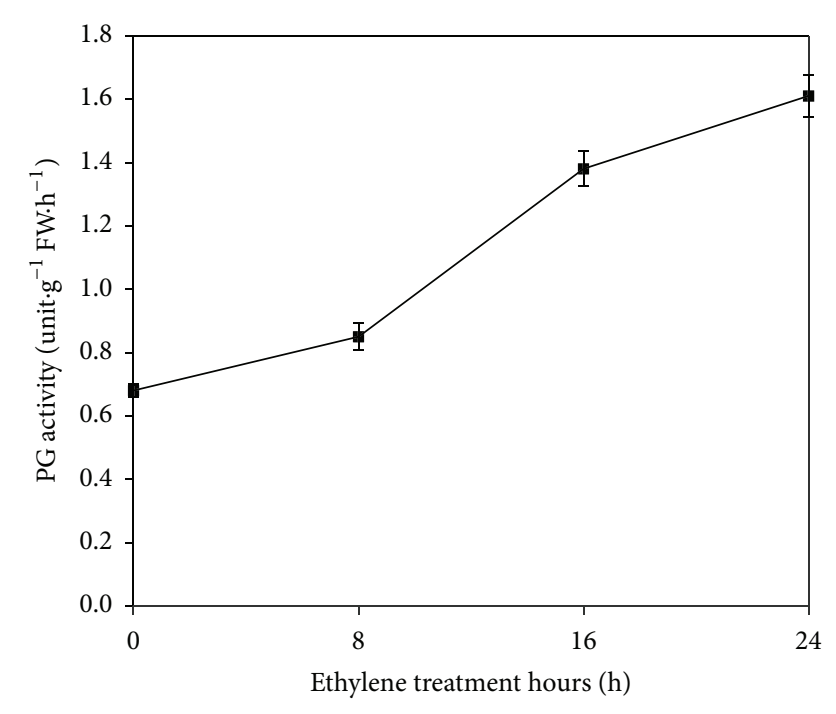

FIGURE 2: Effect of ethylene on polygalacturonase (PG) activity in tomato pedicel explants. Vertical bars indicate \pm S.E. $(n=3)$.

\section{Materials and Methods}

2.1. Plant Material and Ethylene Treatment. Liaoyuanduoli, an indeterminate and popular tomato (Lycopersicon esculentum Mill.) variety in Northeast China, was used and cultured as previously mentioned $[13,14]$. The flowers were collected when all the petals opened. The opening angle was $90^{\circ}$ or more, and the color of the petals was fresh yellow. Floral explants were excised from the inflorescence and immediately used for experiments.

2.2. Ethylene Treatment. Two transparent glass containers were used for ethylene treatment [14]. Pure ethylene (purity: 99.99\%, from Shenyang Beidu Special Gas Co., Ltd.) was injected into the container, and the ethylene concentration was maintained at $20 \mu \mathrm{L} \mathrm{L}^{-1}$. After $0,8,16$, and $24 \mathrm{~h}$, the relative abscission rate was investigated, and the abscission zone was excised to locate PGs. Forty explants served as one replicate.

2.3. Analysis of PG Activity. PG activity was measured according to the method of Wang et al. [14]. One unit of activity was defined as a $1 \%$ loss in the reaction solution viscosity per $1 \mathrm{~h}$ per $1 \mathrm{~g}$ of fresh tissue.

2.4. PG Antibody Production. We obtained a PG antibody from Abmart (Shanghai, China) using New Zealand white rabbits according to the published sequences of TAPG 1 (5364) in NCBI:C-NKPSTINVPIGK-NH2 [13].

2.5. Frozen Section and Immunofluorescence Staining. Tomato pedicel abscission zones (approximately $3 \mathrm{~mm}$ ) were cut using a double-sided blade and then fixed with formaldehyde and glutaraldehyde (4\% formaldehyde : 0.5\% glutaraldehyde $=1: 1$ ) for $1 \mathrm{~h}$ at $4^{\circ} \mathrm{C}$. The abscission zone was embedded in optimal cutting temperature compound, frozen, and then sectioned to $50 \mu \mathrm{m}$ thickness with a Leica CM1850 (Germany) frozen section machine.

Afterward, the frozen section was blocked with $2 \%$ bovine serum albumin for $30 \mathrm{~min}$ at $37^{\circ} \mathrm{C}$, and excess serum around the tissue was removed. The section was added with PG antibody (used at a dilution 1:50) and then incubated at $37^{\circ} \mathrm{C}$ overnight. The slides were rinsed thoroughly with phosphatebuffered saline (PBS), and excess PBS around the tissue was removed. Subsequently, the sample was added with antirabbit Cy3-conjugated secondary antibody (Wuhan Boster Bio-engineering Limited Company, China) and then incubated for $30 \mathrm{~min}$ at $37^{\circ} \mathrm{C}$. The sample was rinsed thoroughly with PBS and then mounted with glycerin. Observations were conducted with a confocal laser scanning microscope (ZEISS, LSM) at excitation and emission wavelengths of 554 and $570 \mathrm{~nm}$, respectively.

2.6. Ultrathin Sections and Immunogold Staining. Tomato pedicel abscission zones (approximately $3 \mathrm{~mm}$ ) were cut using a double-sided blade and then fixed in a PBS mixture of formaldehyde and glutaraldehyde (4\% formaldehyde : $0.5 \%$ glutaraldehyde $=1: 1$ ) for $3 \mathrm{~h}$ at $4^{\circ} \mathrm{C}$. Osmium tetroxide was subsequently added, and fixing was continued for $1 \mathrm{~h}$.

After fixing, the tissue materials were washed in 0.1 M PBS (pH 7.4) and then dehydrated through 70\%, 80\%, 90\%, and $95 \%$ ethanol ( $30 \mathrm{~min}$ per step). The sections were infiltrated for $1 \mathrm{~h}$ with $1: 1 \mathrm{LR}$ white acrylic resin, $100 \%$ ethanol, and then in pure LR white for $24 \mathrm{~h}$. Final embedding was conducted in gelatin capsules, followed by polymerization in an oven at $60^{\circ} \mathrm{C}$ for $36 \mathrm{~h}$.

After complete polymerization, the abscission zone tissues were obtained and made into ultrathin sections $(50 \mathrm{~nm})$. The sections were collected on formvar-carbon-coated nickel grids and allowed to dry overnight prior to staining.

The sections were rinsed twice ( 2 min each) with PBSTween 20. After being blocked in $2 \%$ bovine serum albumin for $30 \mathrm{~min}$ at $37^{\circ} \mathrm{C}$, slide-mounted sections were covered in a droplet of primary antibody and incubated overnight at $4^{\circ} \mathrm{C}$.

The primary antibody against PG and the immunogold reagent were diluted to $1: 50$ and 1:100 (15 nm, Bio-Rad Laboratories, USA), respectively, with $50 \mathrm{mM}$ phosphatebuffered saline at $\mathrm{pH}$ 7.2.

The sections were rinsed three times ( 2 min each) with PBS-Tween 20 and then incubated with the immunogold 

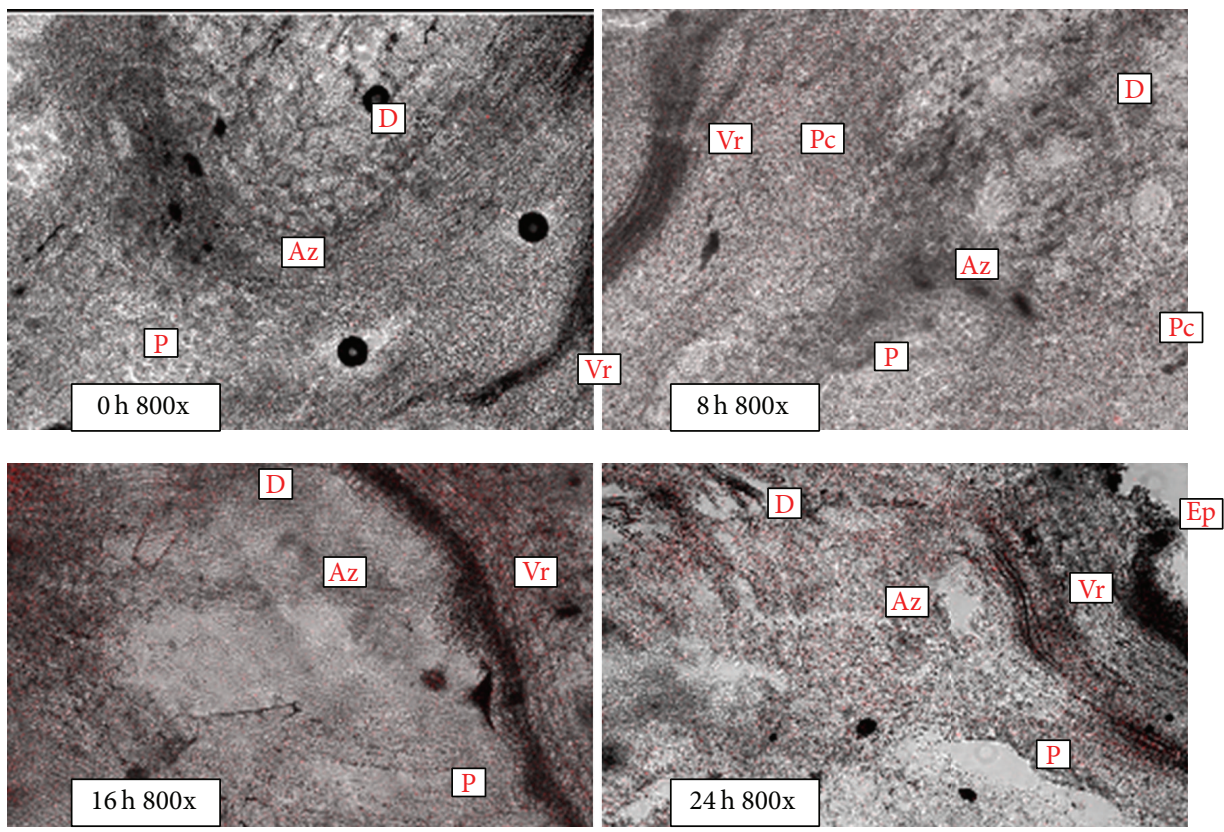

FIGURE 3: Immunolocalization of polygalacturonase (PG) in tomato pedicel with Cy3 fluorescent labeling. D, Az, and P indicate the distal, abscission zone, and proximal side, respectively. Pc: parenchyma cells; Ep: epidermis; Vr: vascular bundle region.

reagent at $37^{\circ} \mathrm{C}$ for $30 \mathrm{~min}$. The sample was rinsed thrice ( 2 min each) with PBS-Tween20 and then with distilled water before it was allowed to dry at room temperature.

The treated sections were observed and photomicrographed with a transmission electron microscope (JEM100CX-II, Japan).

\section{Results}

3.1. Effects of Ethylene on Pedicel Explant Abscission and PG Activity. The abscission rate and PG activity of the tomato pedicel explants treated with ethylene were investigated throughout the $24 \mathrm{~h}$ treatment (Figures 1 and 2 ). A few pedicel explants separated from the plant, the abscission rate rapidly increased, and $100 \%$ abscission rate was reached at 8,16 , and $24 \mathrm{~h}$ after ethylene treatment, respectively. Similar to the abscission rate, $\mathrm{PG}$ activity was relatively low at 0 and $8 \mathrm{~h}$ after ethylene treatment but increased rapidly at 16 and $24 \mathrm{~h}$ after the treatment. These results suggested that PG activity and abscission rate were closely related.

\subsection{Cellular Location of PG in the Abscission Zone during} Ethylene-Induced Abscission. PG activity is closely correlated with abscission. Thus, understanding the function of PG in abscission would be helpful in locating PG in the abscission zone. Thus, we observed the distribution of PG in the abscission zone during ethylene-stimulated abscission using a fluorescent antibody-Cy3-conjugated secondary antibody (Figure 3). Results showed that Cy3 fluorescent labeling of the abscission zone containing dense small cells was very weak at the beginning of ethylene treatment. At $8 \mathrm{~h}$ after ethylene treatment, the fluorescent labeling strengthened throughout the abscission zone, especially in the parenchyma cells around the vascular tissue. The fluorescent level further increased at $16 \mathrm{~h}$ after the treatment. When the abscission layer was formed at $24 \mathrm{~h}$ after ethylene treatment, the distribution of fluorescent labeling presented an even higher level at the abscission zone.

3.3. Subcellular Location of PG in the Abscission Zone during Ethylene-Induced Abscission. To find the accurate location of PG in the abscission zone, immunogold staining was further used to fix the position of PG at the cellular level. The results showed that the abscission zone tissue was intact and well structured at $0 \mathrm{~h}$ after ethylene treatment (Figure 4 ). The cortical cells had thick cytoplasm, cell membrane, and cell wall. At this point, a very small amount of gold particles was observed in the cells of the cortex and vascular tissues, in the cell wall, or in the cytoplasm near the cell wall (Figures 4(a) to 4(d)). Gold particles were not observed in the vacuole (Figure 4(e)) and nucleus (Figure 4(f)). These results suggested that PGs were expressed in the cells of the abscission zone but at a low level before the initiation of abscission.

At $8 \mathrm{~h}$ after ethylene treatment, the structure of most of the unseparated pedicels remained intact and showed no significant differences (Figure 5). However, the gold particles increased significantly in the parenchyma cells in the cortex (Figure 5(b)) and vascular tissues (Figure 5(d)), as well as in the central parenchyma cells (Figures 5(e) and 5(f)). Similar to the observation at $0 \mathrm{~h}$, most of the gold particles were still near the cell wall.

After $16 \mathrm{~h}$ of ethylene treatment (Figure 6), abscission zone tissues started to decompose, and part of the cortical cells began to break down. As a result, the cell structure and cell wall in some areas were destroyed, and plasmolysis began 


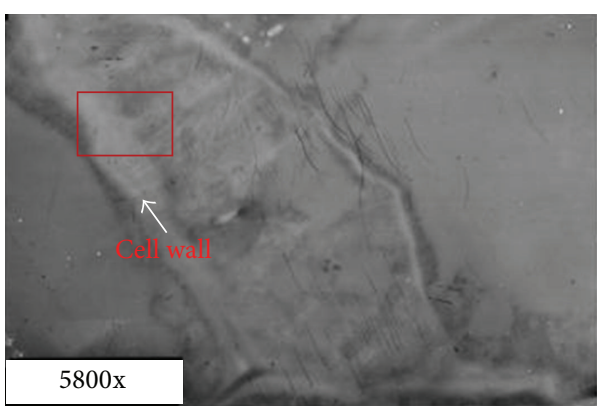

(a)

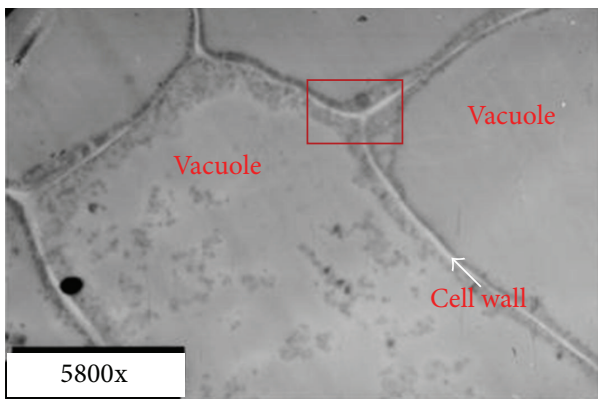

(c)

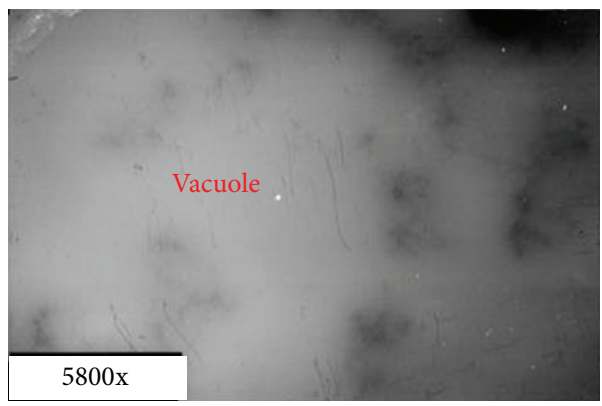

(e)

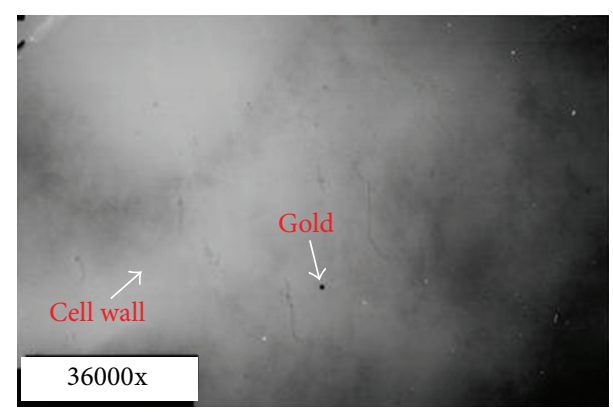

(b)

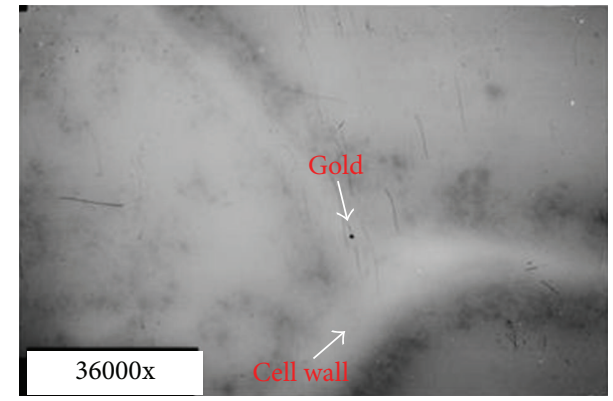

(d)

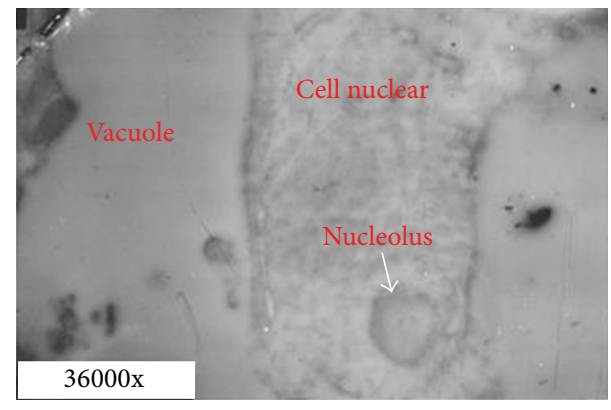

(f)

FIGURE 4: Transmission electron micrographs of tomato pedicel and localization of polygalacturonase (PG) in abscission zone cells with immunogold labeling (0 h). (a) and (b): cortex; (c) and (d): central parenchymatous region; (e): vacuole; (f): cell nucleus; (b) and (d) are enlarged photos for the rectangles region in (a) and (c), respectively.

to occur (Figure 6(a)). The structure of the vascular tissue was also damaged, and the cells were deformed (Figure 6(c)). The parenchyma cells in the central region became oval and were about to separate (Figure 6(d)). At this point, a large amount of gold particles were distributed in various parts of the organization, especially in the cortical cells (Figure 6(b)). Most of the gold particles were distributed in the cell wall, cell membrane, and neighboring cytoplasm. Gold particles were also observed in the vacuole (Figures 6(g) and 6(h)). These results suggested that polygalacturonic acid enzymes were involved in cell wall degradation and that their expression was closely related to abscission.

After $24 \mathrm{~h}$ of ethylene treatment, the abscission zone tissue was completely broken down into two parts: proximal side (Figure 7) and distal side (Figure 8). On the surface of the abscission zone, cell structure completely decomposed and showed a diffusion-like distribution. The cell wall of inside cells degraded, and most of the cells were free.
The cells with severe degradation lost inclusions (Figure 7). At this point, a large number of gold particles were distributed at the proximal side of the abscission zone. Gold particles also gathered in some regions. These findings indicated that the existence of a large number of polygalacturonic acid enzymes in the abscission tissue was crucial in the degradation of the cell wall and other substances. In addition, a large number of gold particles were observed on the distal side of the abscission zone (Figure 8), indicating that the polygalacturonic acid enzyme was expressed in all organizations, including the proximal and distal sides of the abscission zone.

\section{Discussion}

The results clearly demonstrated the distribution of PG in the tomato pedicel abscission zone after immunogold staining. Since Faulk and Taylor [15] first used immunogold staining 


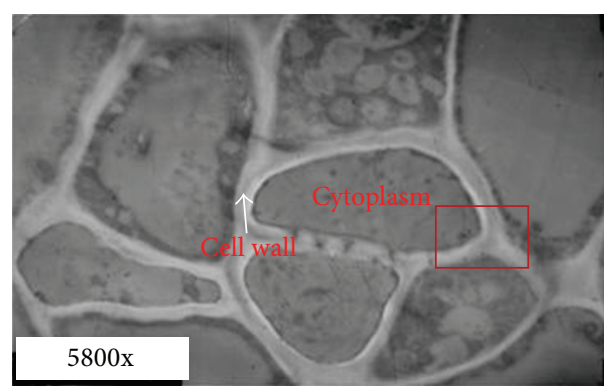

(a)

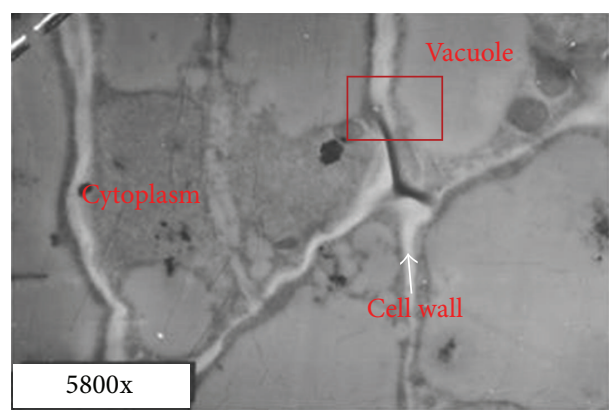

(c)

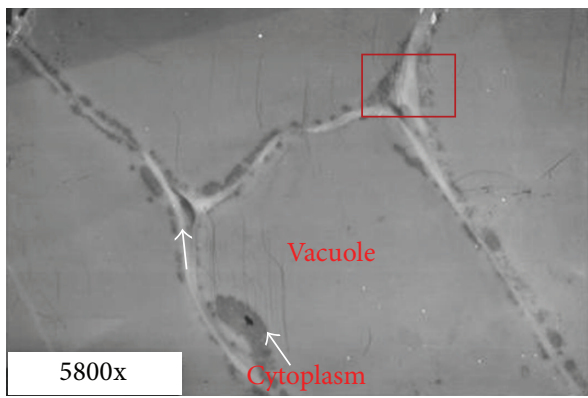

(e)

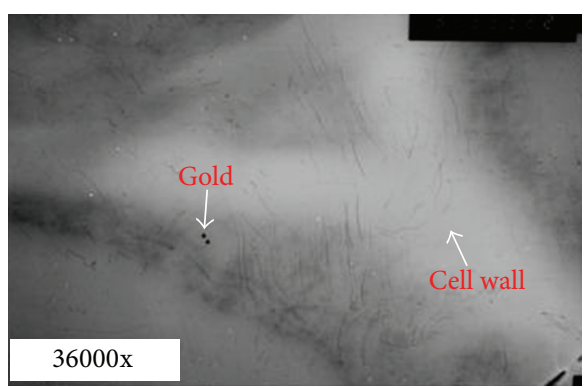

(b)

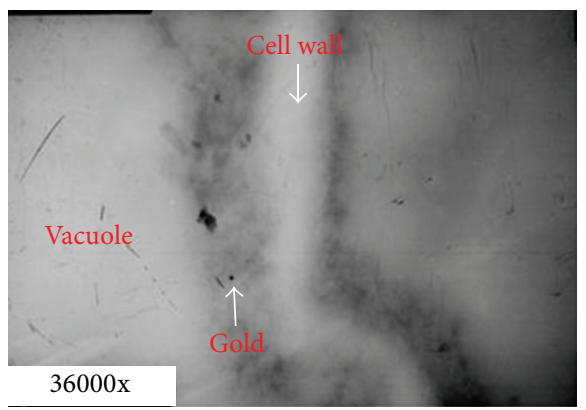

(d)

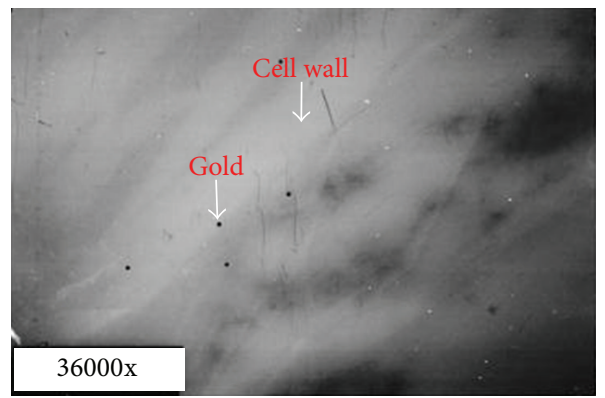

(f)

FIGURE 5: Transmission electron micrographs of tomato pedicel and localization of polygalacturonase (PG) in abscission zone cells by immunogold labeling (8h). (a) and (b): cortex; (c) and (d): vascular region; (e) and (f): central parenchymatous region (b); (d) and (f) are enlarged photos for the rectangles region in (a), (c), and (e), respectively.

to demonstrate antigens by electron microscopy, various modifications have helped improve the sensitivity of the method, which has now become a mature technology in immunohistochemistry [16-18]. Cellular localization of the endo-PG protein in Arabidopsis siliques was determined by Sander et al. [19]. They showed that PG is confined to the dehiscence zone, which is similar to the abscission zone. In the present study, we used two dimensions of colloidal gold (10 and $15 \mathrm{~nm}$ ). However, $10 \mathrm{~nm}$ colloidal gold particles are difficult to detect within the scope of electron microscopy (data not shown). Hence, we recommend the use of $15 \mathrm{~nm}$ colloidal gold particles in future research.

The tomato pedicel abscission zone is ideal for observing abscission. This zone contains several layers of small and regular cells with dense cytoplasm. Its morphology can also be easily distinguished from other tissues. Thus, samples can be cut by hand, and the exact location of the abscission zone can be found easily through electron microscopy.
The activity of PG is correlated with abscission in different plant varieties; PG is also an indicator of the progress of abscission [8, 10, 20-25]. At the gene level, Kalaitzis et al. [10] pointed out that three PGs (TAPG1, TAPG2, and TAPG4) are expressed in the leaf and flower abscission zones as well as in the pistils of fully opened flowers. However, TAPG4 mRNA is detected much earlier than TAPGl and TAPGZ mRNA during both leaf and flower abscission. González-Carranza et al. [25] detected PG gene expression in cells at the base of the anther filament (stamen), petals, and sepals in the flowers of transgenic Arabidopsis. At the enzyme level, Robert [26] revealed that the related PG activity is only limited to the distal part of the abscission zone. However, Wang et al. [14] indicated that PG activity is significantly increased at the distal and proximal ends of the tomato pedicel abscission zone during separation. In the present paper, PG initially increased in the parenchyma cells in the cortex and vascular tissues in the abscission zone, along the side of the vascular 


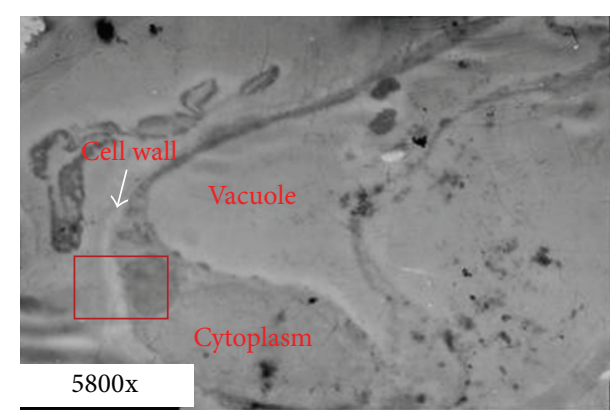

(a)

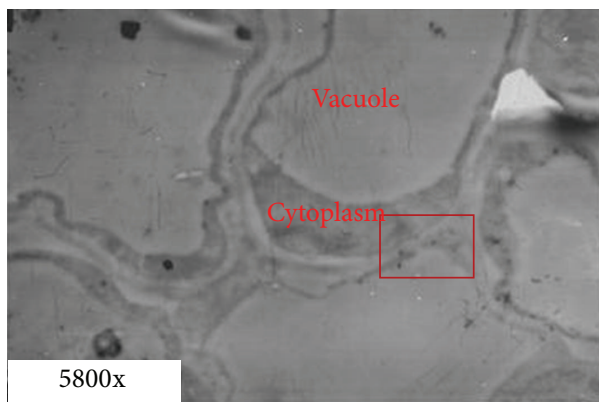

(c)

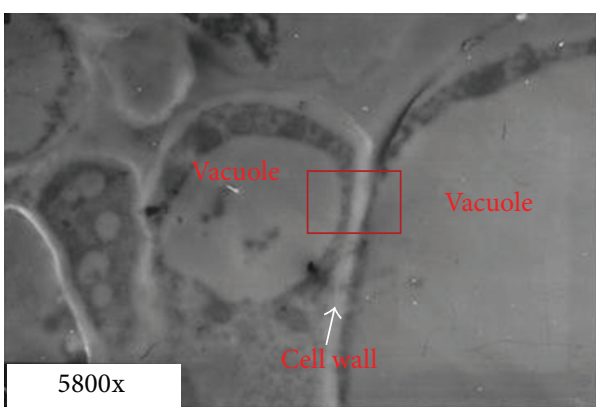

(e)

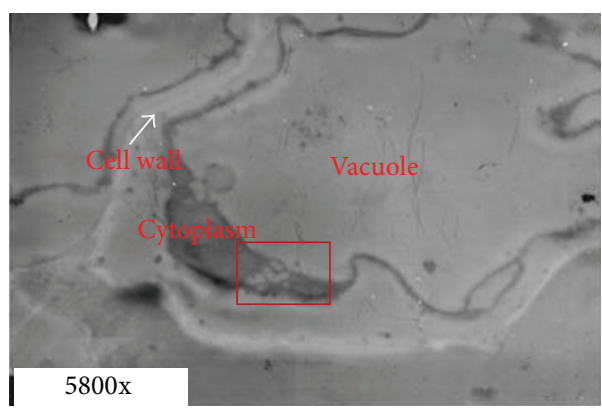

(g)

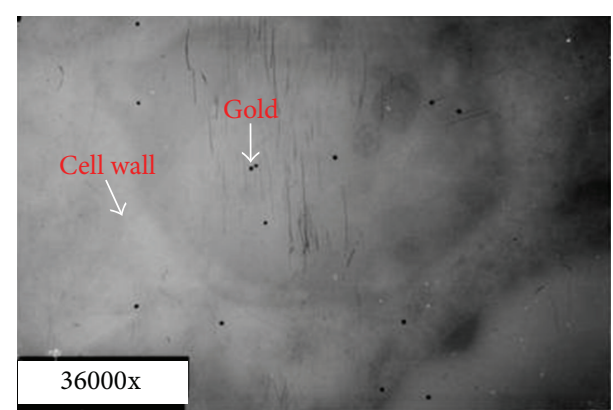

(b)

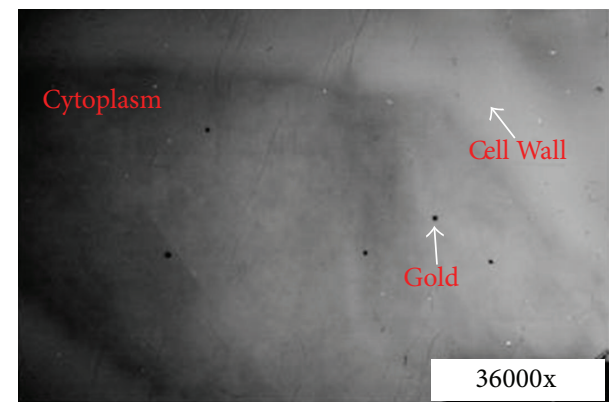

(d)

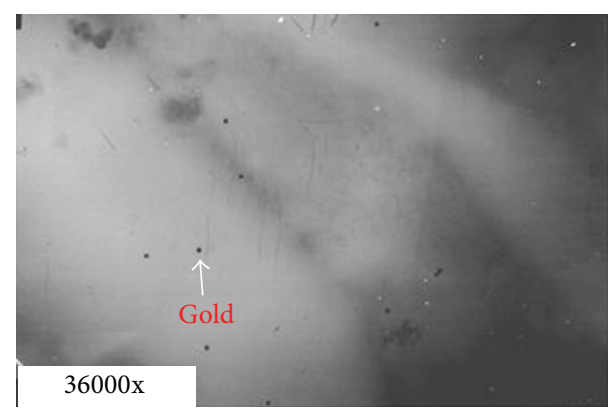

(f)

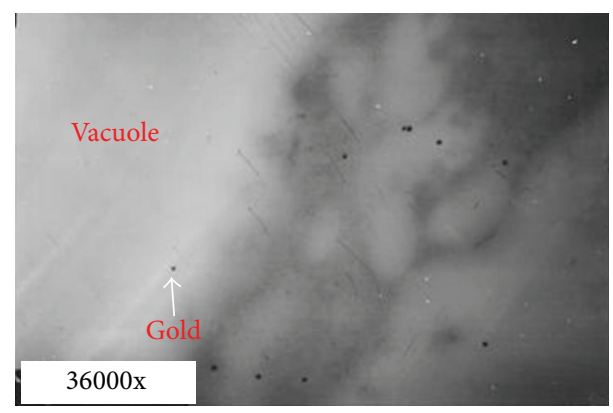

(h)

Figure 6: Transmission electron micrographs of tomato pedicel and localization of polygalacturonase (PG) in abscission zone cells by immunogold labeling (16 h). (a) and (b): cortex; (c) and (d): vascular region; (e) and (f): central parenchymatous region; (g) and (h): vacuole; (b), (d), (f), and (h) are enlarged photos for the rectangles region in (a), (c), (e), and (g), respectively.

tissue extending to the distal and proximal ends, and then lateral from outside to the central region of the abscission zone. These results suggested that PG was closely related to abscission. At first, PG was only observed in the cell wall and nearby region. However, it also appeared in the nucleus during separation, which showed the de novo biosynthesis of PG in abscission.
In abscission, $\mathrm{PG}$ is responsible for the degradation of the middle lamella and for the loosening of the primary cell wall. Recently, alterations in the chemical composition of the cell wall during abscission have indicated that the deposition of certain substances, such as xyloglucan and galactan for floral abscission and lignin for fruit, occurs specifically at the abscission zone [27]. Thompson and Osborne [28] 


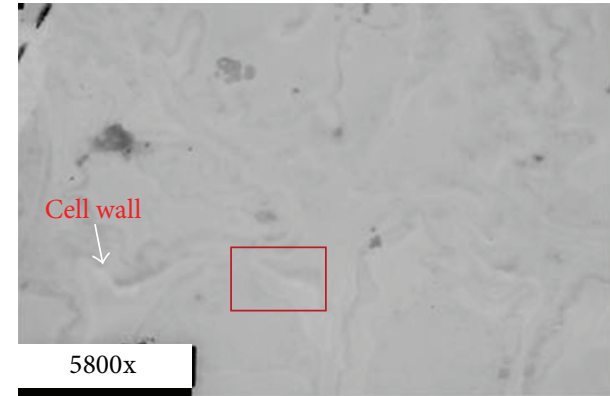

(a)

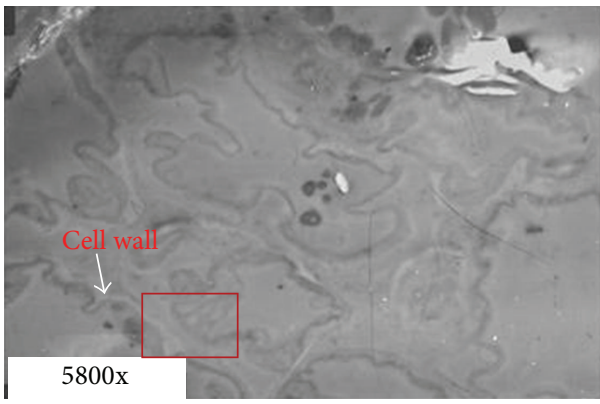

(c)

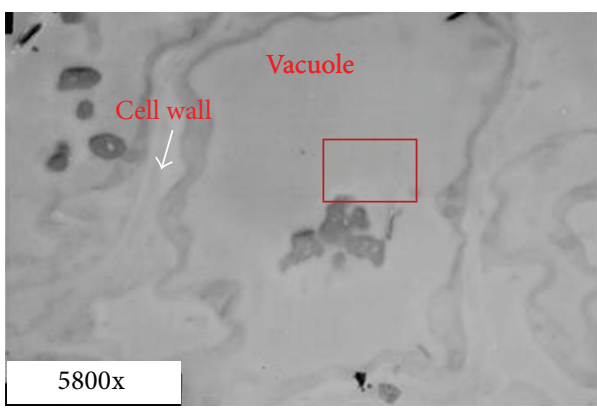

(e)

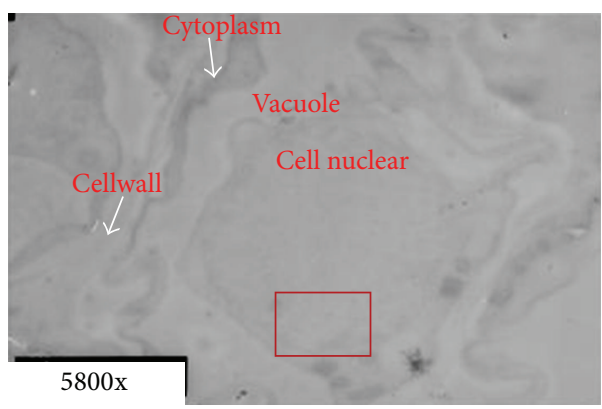

(g)

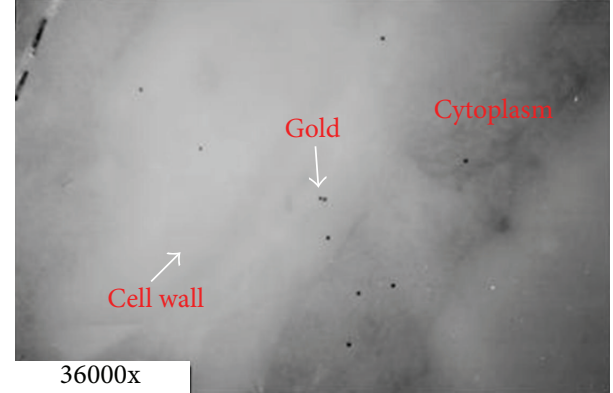

(b)

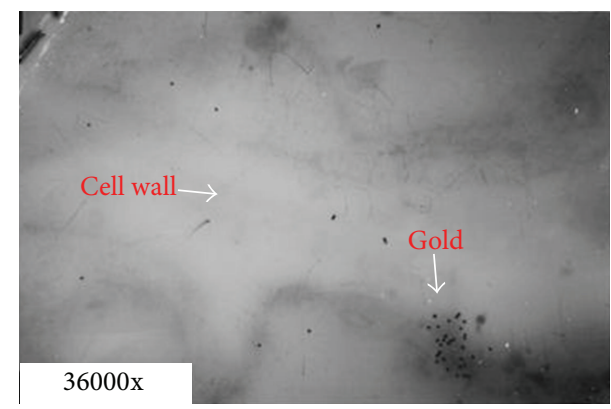

(d)

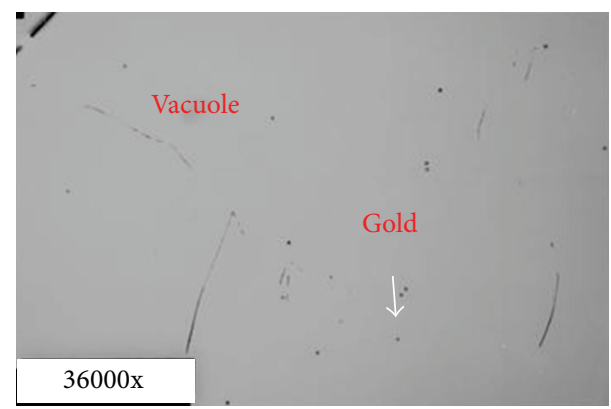

(f)

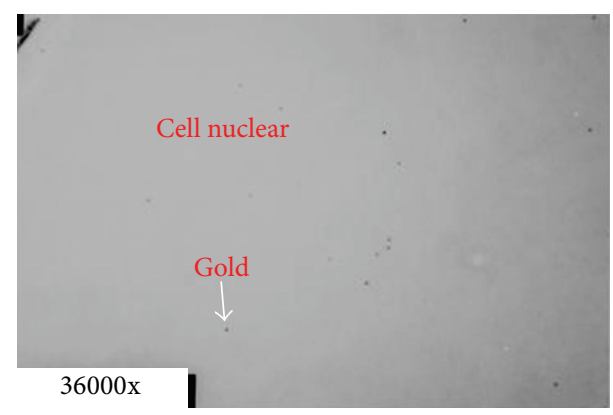

(h)

Figure 7: Transmission electron micrographs of tomato pedicel and localization of polygalacturonase (PG) in abscission zone cells by immunogold labeling (proximal end, $24 \mathrm{~h}$ ). (a) and (b): cortex; (c) and (d): vascular region; (e) and (f): vacuole; (g) and (h): cell nucleus; (b), (d), (f), and (h) are enlarged photos for the rectangles region in (a), (c), (e), and (g), respectively. 


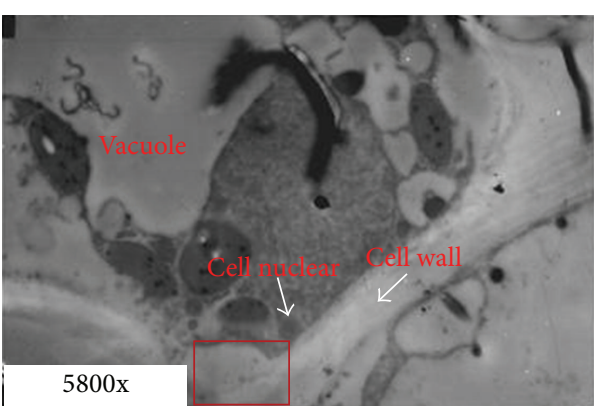

(a)

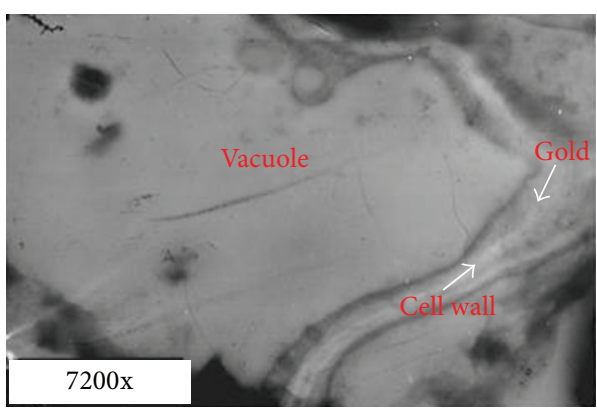

(c)

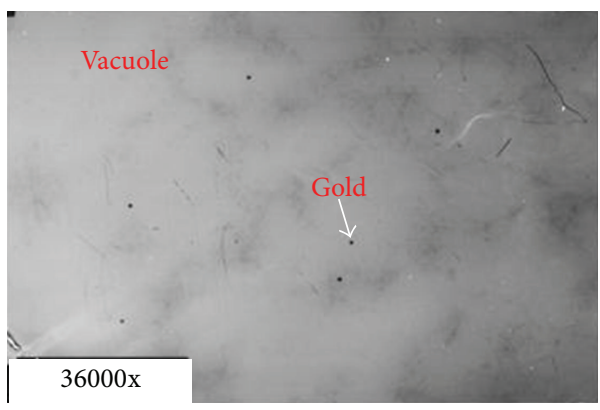

(e)

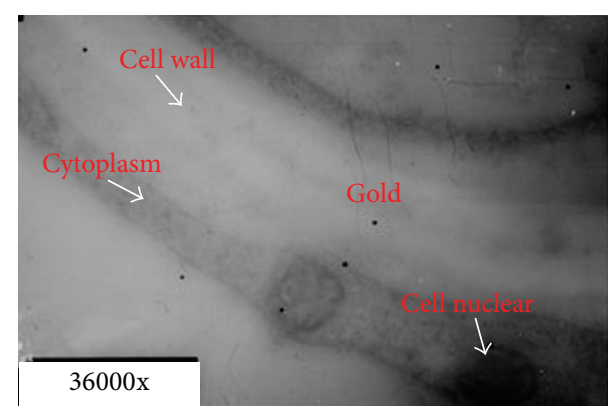

(b)

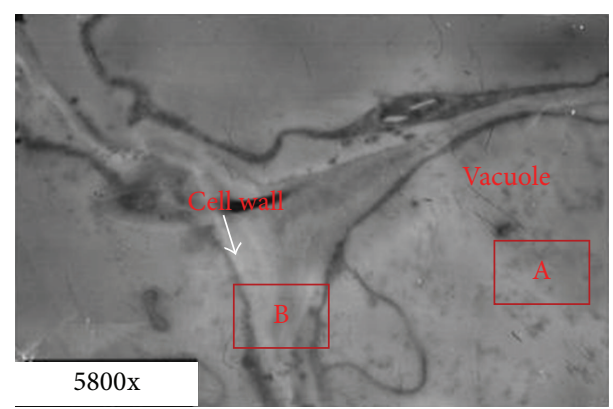

(d)

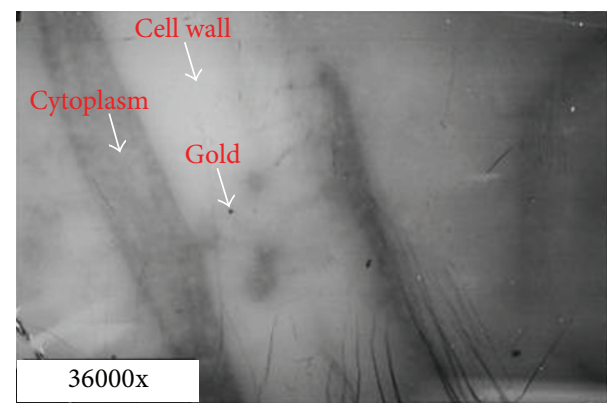

(f)

FIGURE 8: Transmission electron micrographs of tomato pedicel and localization of polygalacturonase (PG) in abscission zone cells by immunogold labeling (Distal end, $24 \mathrm{~h}$ ). (a), (b), and (c): cortex; (d), (e), and (f): vascular region; (b) is enlarged photo for the rectangles region in (a); (e) and (f) are enlarged photos for the rectangles region of A and B in (d), respectively.

demonstrated that the stele is the source of abscission and speculated that an oligosaccharide released from the cell walls of the stele may act as the signal for cortical cells to begin cell separation at the tomato pedicel abscission zone. Kalaitzis et al. [10] then believed that the early expression of TAPG4 is involved in a similar signaling process in tomato. In this trial, the increase in PG was first found only at the cell wall region of the cortical and vascular regions in the abscission zone and then along the vascular tissue extending to the distal and proximal ends. These results suggested the function of PG in producing the abscission signal and degrading the middle lamella.

\section{Conflict of Interests}

The authors declare that there is no conflict of interests regarding the publication of this paper.

\section{Acknowledgments}

This work was supported by the National Natural Science Foundation of China (Grant no. 31071789), the 12th FiveYear Support Project of China (Grant no.: 2011BAD12B03), and the Program for Liaoning Excellent Talents in University (LJQ2011069).

\section{References}

[1] J. E. Taylor and C. A. Whitelaw, "Signals in abscission," New Phytologist, vol. 151, no. 2, pp. 323-339, 2001.

[2] R. Sexton and J. A. Roberts, “Cell biology of abscission," Annual Review of Plant Physiology, vol. 33, no. 1, pp. 133-162, 1982.

[3] S. J. Liljegren, "Organ abscission: exit strategies require signals and moving traffic," vol. 15, no. 6, pp. 670-676, 2012. 
[4] F. B. Abeles and B. Rubinstein, "Regulation of ethylene evolution and leaf abscission by auxin," Plant Physiology, vol. 39, no. 6, pp. 963-969, 1964.

[5] B. Rubinstein and A. C. Leopold, "Analysis of the auxin control of bean leaf abscission," Plant Physiology, vol. 38, no. 3, pp. 262267, 1963.

[6] X. Wang, D. Liu, A. Li et al., "Transcriptome analysis of tomato flower pedicel tissues reveals abscission zone-specific modulation of key meristem activity genes," PLOS ONE, vol. 8, no. 2, Article ID e55238, 2013.

[7] C.-Z. Jiang, F. Lu, W. Imsabai, S. Meir, and M. S. Reid, "Silencing polygalacturonase expression inhibits tomato petiole abscission," Journal of Experimental Botany, vol. 59, no. 4, pp. 973-979, 2008.

[8] Z. H. González-Carranza, K. A. Elliott, and J. A. Roberts, "Expression of polygalacturonases and evidence to support their role during cell separation processes in arabidopsis thaliana," Journal of Experimental Botany, vol. 58, no. 13, pp. 3719-3730, 2007.

[9] M. L. Tucker, A. Burke, C. A. Murphy, V. K. Thai, and M. L. Ehrenfried, "Gene expression profiles for cell wall-modifying proteins associated with soybean cyst nematode infection, petiole abscission, root tips, flowers, apical buds, and leaves," Journal of Experimental Botany, vol. 58, no. 12, pp. 3395-3406, 2007.

[10] P. Kalaitzis, T. Solomos, and M. L. Tucker, "Three different polygalacturonases are expressed in tomato leaf and flower abscission, each with a different temporal expression pattern," Plant Physiology, vol. 113, no. 4, pp. 1303-1308, 1997.

[11] Z. H. Gonzalez-Carranza, A. A. Shahid, L. Zhang, Y. Liu, U. Ninsuwan, and J. A. Roberts, "A novel approach to dissect the abscission process in arabidopsis," Plant Physiology, vol. 160, no. 3, pp. 1342-1356, 2012.

[12] T. Bar-Dror, M. Dermastia, A. Kladnik et al., "Programmed cell death occurs asymmetrically during abscission in tomato," The Plant Cell, vol. 23, no. 11, pp. 4146-4163, 2011.

[13] T. Xu, T. Li, and M. Qi, "Calcium effects on mediating polygalacturonan activity by mRNA expression and protein accumulation during tomato pedicel explant abscission," Plant Growth Regulation, vol. 60, no. 3, pp. 255-263, 2010.

[14] Y. Wang, T. Li, H. Meng, and X. Sun, "Optimal and spatial analysis of hormones, degrading enzymes and isozyme profiles in tomato pedicel explants during ethylene-induced abscission," Plant Growth Regulation, vol. 46, no. 2, pp. 97-107, 2005.

[15] W. P. Faulk and G. M. Taylor, "An immunocolloid method for the electron microscope," Immunochemistry, vol. 8, no. 11, pp. 1081-1083, 1971.

[16] W. D. Geoghegan and G. A. Ackerman, "Adsorption of horseradish peroxidase, ovomucoid and antiimmunoglobulin to colloidal gold for the indirect detection of concanavalin A, wheat germ agglutinin and goat antihuman immunoglobulin $\mathrm{G}$ on cell surfaces at the electron microscopic level: a new method, theory and application," Journal of Histochemistry \& Cytochemistry, vol. 25, no. 11, pp. 1187-1200, 1977.

[17] C. S. Holgate, P. Jackson, P. N. Cowen, and C. C. Bird, "Immunogold-silver staining: new method of immunostaining with enhanced sensitivity," Journal of Histochemistry and Cytochemistry, vol. 31, no. 7, pp. 938-944, 1983.

[18] G. Danscher, "Localization of gold in biological tissue," Histochemistry, vol. 71, no. 1, pp. 81-88, 1981.

[19] L. Sander, R. Child, P. Ulvskov, M. Albrechtsen, and B. Borkhardt, "Analysis of a dehiscence zone endo-polygal- acturonase in oilseed rape (Brassica napus) and Arabidopsis thaliana: evidence for roles in cell separation in dehiscence and abscission zones, and in stylar tissues during pollen tube growth," Plant Molecular Biology, vol. 46, no. 4, pp. 469-479, 2001.

[20] L. Trainotti, N. Rascio, and G. Casadoro, "Expression of an endopolygalacturonase gene during growth and abscission of peach fruits," Hereditas, vol. 119, no. 3, pp. 301-304, 1993.

[21] J. Kim and S. E. Patterson, "Expression divergence and functional redundancy of polygalacturonases in floral organ abscission," Plant Signaling \& Behavior, vol. 1, no. 6, pp. 281-283, 2006.

[22] R. K. Berger and P. D. Reid, "Role of polygalacturonase in bean leaf abscission," Plant Physiology, vol. 63, no. 6, pp. 1133-1137, 1979.

[23] M. H. Asif and P. Nath, "Expression of multiple forms of polygalacturonase gene during ripening in banana fruit," Plant Physiology and Biochemistry, vol. 43, no. 2, pp. 177-184, 2005.

[24] R. G. Atkinson, R. Schröder, I. C. Hallett, D. Cohen, and E. A. MacRae, "Overexpression of polygalacturonase in transgenic apple trees leads to a range of novel phenotypes involving changes in cell adhesion," Plant Physiology, vol. 129, no. 1, pp. 122-133, 2002.

[25] Z. H. González-Carranza, C. A. Whitelaw, R. Swarup, and J. A. Roberts, "Temporal and spatial expression of a polygalacturonase during leaf and flower abscission in oilseed rape and arabidopsis," Plant Physiology, vol. 128, no. 2, pp. 534-543, 2002.

[26] J. A. Roberts, J. Taylor, Y. V. Lasslett, and G. A. Tucker, "Changes in gene expression during ethylene-induced leaf abscission," Cell Separation in Plants, vol. 35, pp. 61-68, 1989.

[27] H. Iwai, A. Terao, and S. Satoh, "Changes in distribution of cell wall polysaccharides in floral and fruit abscission zones during fruit development in tomato (Solanum lycopersicum)," Journal of Plant Research, vol. 126, no. 3, pp. 427-437, 2013.

[28] D. S. Thompson and D. J. Osborne, "A role for the stele in intertissue signaling in the initiation of abscission in bean leaves (Phaseolus vulgaris L.)," Plant Physiology, vol. 105, no. 1, pp. 341$347,1994$. 


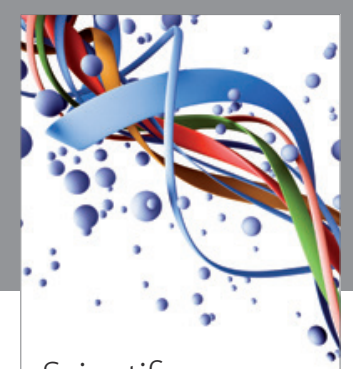

Scientifica
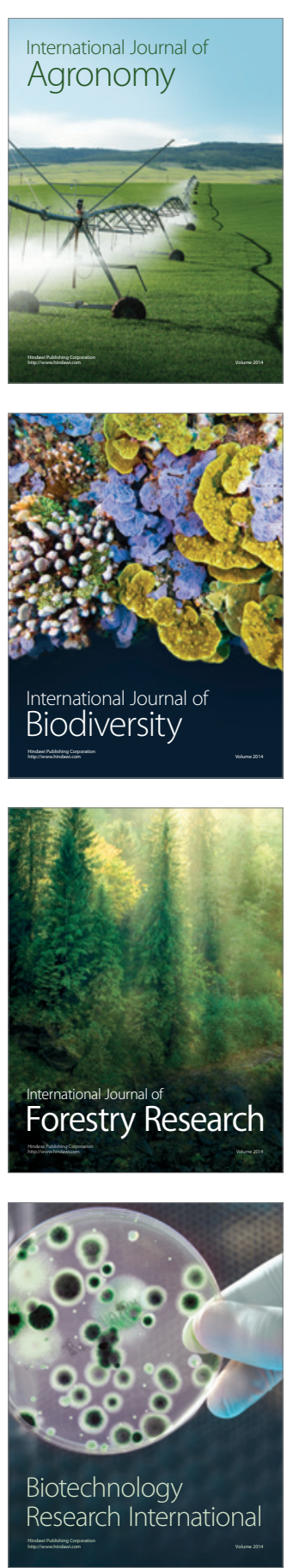
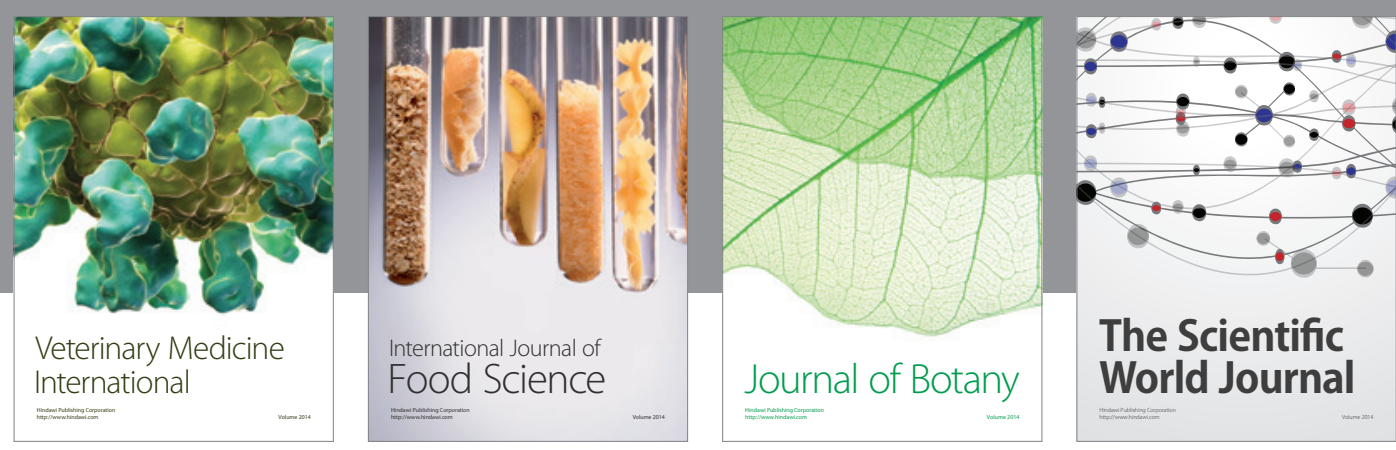

The Scientific World Journal
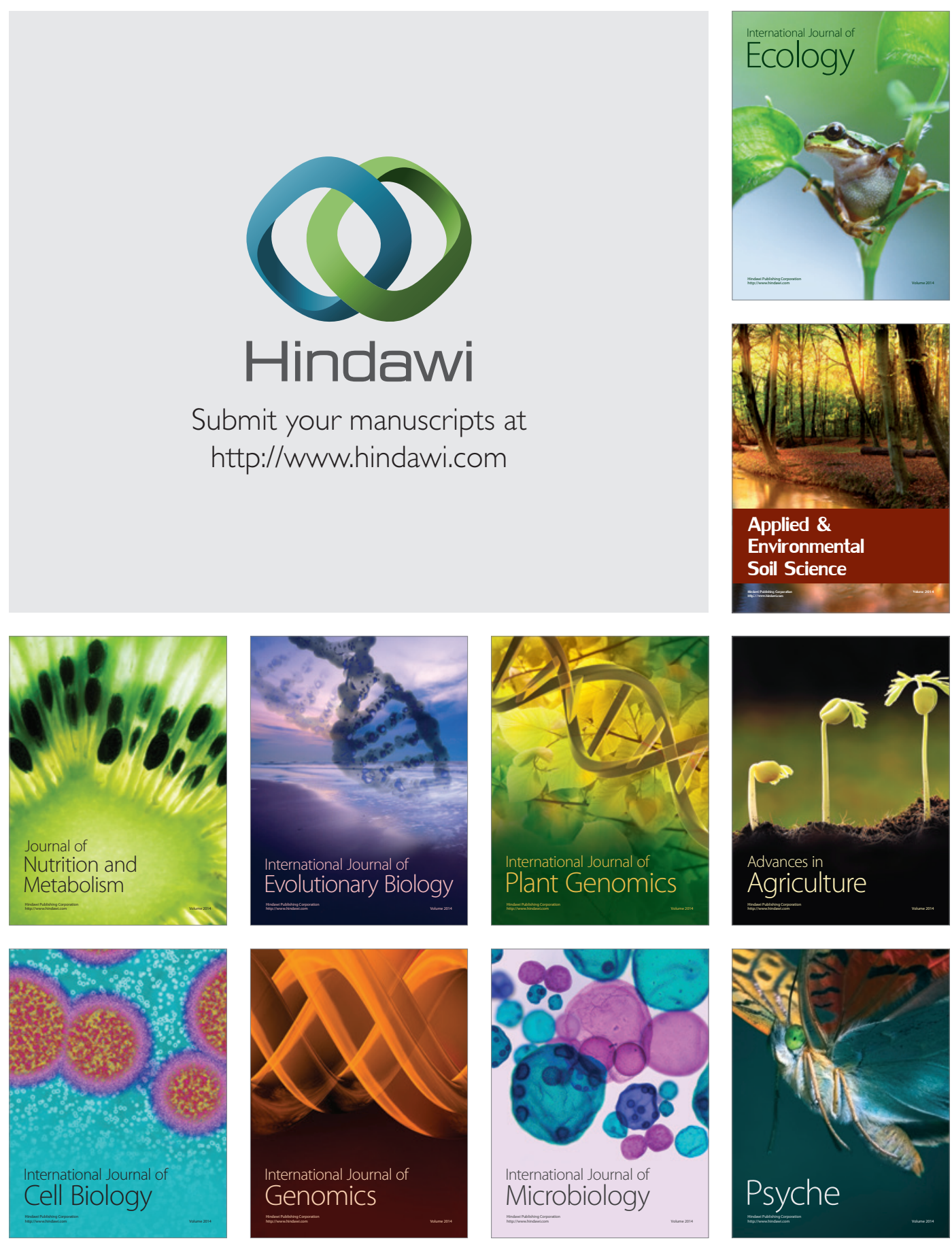